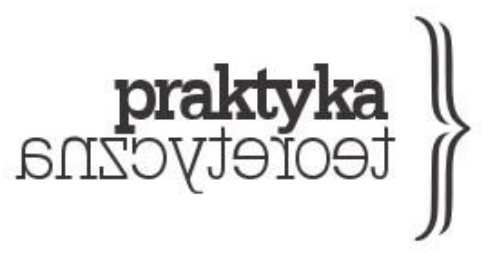

\title{
MARKS BEZ ORGANÓW
}

\section{CEZARY RUDNICKI}

\begin{abstract}
Abstrakt: Niniejszy tekst stanowi próbę ukazania związków pomiędzy myślą Marksa a przedstawiona w Anty-Edypie ontologia pragnienia. Zabiegiem kluczowym dla wydobycia relacji pomiędzy tymi dwoma projektami filozoficznymi będzie pominięcie wszelkich odniesień do psychoanalizy. Toteż podstawowe, organizujące siatkę teoretyczną Anty-Edypa pojęcia, takie jak pragnienie, ciało, nieświadomość, kod, brak, a nawet Edyp, zostaną objaśnione bez odniesienia do pism Freuda, Lacana czy Melanie Klein. Tym ostatnim poświęcano dotąd zbyt wiele uwag, w efekcie zawężając krag odbiorców dzieła Deleuze’a i Guattariego. Wydaje się, że komunikacyjna blokada powstała przede wszystkim pomiędzy Anty-Edypem a środowiskiem marksistowskim (nie licząc kilku drobnych wyjątków). Jest to kanał, który należałoby wreszcie udrożnić.
\end{abstract}

Słowa kluczowe: praca, pragnienie, ciało bez organów, fetyszyzm, kod, dług, Edyp. 
Piszemy tylko w szczytowym momencie, który oddziela naszą wiedzę od niewiedzy

i który powoduje przechodzenie jednej w drugą. Wówczas dopiero jesteśmy zmuszeni do pisania. Usunąć niewiedzę to odłożyć pisanie na jutro albo raczej uczynić je niemożliwym.

Gilles Deleuze, Różnica i powtórženie

Ze względu na moją niewielką znajomość pism Deleuze’a i Guattariego (D\&G) oraz nikłą dzieł Marksa, podjęta tu próba musi jawić się co najmniej jako arogancka. Przeczytać AntyEdypa siatką pojęciowa Kapitału. Moge się usprawiedliwiać jedynie infantylną potrzebą zestawiania ze sobą rzeczy gatunkowo obcych oraz pewnym szczątkowym przeszkoleniem w wyłuskiwaniu pojęć spomiędzy twardych okładek grubych woluminów. Jeżeli Czytelnik bądź Czytelniczka zechce wybaczyć mi jeszcze tę słabość, że mój styl nie ma nic wspólnego ani z drobiazgowym pozytywizmem Marksa, ani ze schizofrenicznym strumieniem Deleuzoguattariańskiego pisma, być może uda się Jej lub Jemu dotrwać do końca lektury niniejszego tekstu. Obiecuję ograniczyć się - na tyle, na ile będzie to możliwe - wyłącznie do pierwszych rozdziałów obu wspomnianych dzieł. Nigdy zresztą nie udało mi się dotrzeć wiele dalej1.

Wydaje się, że recepcja Anty-Edypa od początku opierała się na pewnym poważnym nieporozumieniu. Nieustanne odwołania do Freuda, Lacana i Klein, terminy takie jak pragnienie, nieświadomość czy rozkosz, a wreszcie tytuł tego dzieła, sprawiły, że niektórzy i niektóre uznały, iż chodzi w nim o psychoanalizę2. Publiczność zadziwiająco łatwo prześlepiła fakt, że Marksa cytuje się tu równie często co Freuda i Lacana. A jeśli już brano tę kwestię pod uwagę, to albo po to, by opatrzyć projekt D\&G etykietką freudomarksizmu (co miałoby sugerować przynależność do jakiejś „lewicy freudowskiej”), albo po to, by dowodzić, że autorzy poddaja pisma Marksa równie zaciekłej krytyce, jak teksty autora Objaśnienia marzeń sennych (ciekawy komentarz na ten temat: Swianiewicz 2014, 396-397). Podobne nieporozumienie, choć spowodowane innymi czynnikami, obciąża zresztą dzieło

1 W czasie seminarium domowego Czytanie „Anty-Edypa”, w którym uczestniczyłem w roku akademickim 2014/2015, nigdy nie udało się nam wyjść poza pierwszy rozdział dzieła Deleuze’a i Guattariego. Zaś na Czytanie „Kapitału” nigdy nie dotarłem...

2 Być może Deleuze i Guattari nigdy nie mieli szczęścia do tytułów. Wspomnieć można choćby ich ostatnie wspólne dzieło: Co to jest filozofia?. Każdy, kto choć chwilę obcował z ich tekstami wie, że pytanie „co to jest?” przynależy do dogmatycznego obrazu myśli, który poddaja gruntownej krytyce. Właściwym dla Deleuze’a i Guattariego pytaniem jest raczej ,jak to działa?”. 
Marksa. Jego, jak się rzekło, pozytywistyczny styl, różnego rodzaju rachunki, ale także praca na materiale historycznym sprawiły, że niektórzy uwierzyli, iż chodzi mu o coś innego niż o pojęcia i ontologiczną analizę struktur wiedzy. Marksiści chcą dziś być badaczami, kiedy Marks był po prostu - filozofem.

Warto jednak uważniej przyjrzeć się relacjom pomiędzy Anty-Edypem a Kapitałem. W ramach pewnych prolegomenów do takiego przedsięwzięcia pozwolę sobie wyjść od kilku cytatów, w których dokonam podmiany kluczowych terminów - pozwoli nam to uniknąć podstawowego błędu, jakim jest mylenie słowa z pojęciem. (Numeruję owe przytoczenia, aby powracać do nich później bez ponownego ich przepisywania). Najpierw podstawmy u Marksa „pragnienie” w miejsce „pracy”:

(1): Jako twórczyni wartości użytkowych [...] jest tedy [pragnienie] warunkiem istnienia człowieka, niezależnym od wszelkich ustrojów społecznych, jest wieczna, przyrodzoną koniecznością umożliwiającą wymianę materii między człowiekiem a przyroda, a więc umożliwiającą życie ludzkie (Marks 1950, 45).

I dalej:

(2): Wartości użytkowe: surdut, płótno itd., krótko mówiąc, ciała towarów, są połączeniami dwóch pierwiastków: materiału danego przez przyrodę i [pragnienia]. [...] Wytwarzając, człowiek może postępować tylko tak, jak postępuje przyroda, tzn. zmieniać tylko formy materii. Co więcej: w samym [tym] [pragnieniu] kształtowania jest on bezustannie wspomagany przez siły przyrody (Marks 1950, 45-46).

Teraz na odwrót, u D\&G:

(3): Zawsze istnieje jakaś maszyna produkująca przepływ oraz inna, podłączona do niej, która działa, przecinając i pobierając przepływ [...]. [Praca] nie ustaje w łączeniu ciagłego przepływu z obiektami częściowymi [...]. [Praca] wywołuje przepływ, płynie i przecina (Deleuze i Guattari 2017, 9). 
Albo w innym miejscu:

(4): Jeśli [praca] coś wytwarza, wytwarza to, co realne. Jeżeli [praca] jest wytwórca, to może nim być jedynie w rzeczywistym świecie, wytwarzając rzeczywistość $[\ldots]$. [Praca] nie odczuwa żadnego braku, nie brakuje [jej] obiektu (Deleuze i Guattari 2017, 32).

D\&G nie są Freudem czy Lacanem. Pragnienie, o którym piszą, to nie pożądanie stosunku seksualnego (zwłaszcza z rodzicem) ani chęć spełnienia (ostatecznie niemożliwej do rozpoznania) woli Innego. Pragnienie to dla nich prędzej wzięcie do ręki kilofa i wykopanie węgla, przylutowanie elementu do układu scalonego, uszycie surduta. Pragnieniu, tak jak pracy, „nie brakuje obiektu”. Jest ono bowiem wytwarzaniem czegoś realnego (4). Dlatego D\&G nazywaja schizofrenika (czyli czyste upostaciowienie pragnienia) „wytwórca uniwersalnym" (Deleuze i Guattari 2017, 10). Schizofrenik to nie jednostka wymagająca hospitalizacji, ale rzemieślnik, majsterkowicz, brikoler. „Kiedy brikoler podłącza coś do przewodu elektrycznego lub zmienia bieg rzeki, doznawana przez niego satysfakcja nie daje się wyjaśnić gra w »tatę i mamę« czy przyjemnością czerpaną z transgresji” (Deleuze i Guattari 2017, 11). Czytelniczki i czytelnicy Kapitału nie powinni być również zdziwieni, gdy na podstawie pierwszych paragrafów Anty-Edypa wywnioskuja - całkiem słusznie że owo coś podłączone do przewodu elektrycznego lub kilof z wcześniejszego przykładu D\&G nazwaliby organami. Wszak to sam Marks pisał: „Przedmiot, którym robotnik zawładnął bezpośrednio [...] nie jest przedmiotem pracy, lecz środkiem pracy. W ten sposób przedmiot przyrody sam staje się organem jego działania, organem, który dołącza on do organów własnego ciała, na przekór biblii przedłużając swą przyrodzoną postać” (Marks 1950, 190). Ciało rośnie, zyskuje większe możliwości działania, podłączając do siebie coraz to nowe organy.

W swojej najbardziej podstawowej formie pragnienie (czy też maszyny pragnienia) funkcjonuje jako pewna operacja (D\&G mówia „cięcie”) dokonana na ciągłym przepływie materii (3). Zupełnie jak u Marksa, u którego praca to operowanie na materiale danym przez przyrodę (2). Nieświadomość (ta domena pragnienia) nie jest więc wyobrażeniową krainą zaludnioną przez znaczące figury ani intersubiektywną, symboliczną strukturą, ale realnym procesem montowania materialnych układów. Zupełnie serio trzeba potraktować uwage D\&G, że „[p]sychoanalityk zmuszony do wyruszenia w głąb nieświadomości wytwórczej 
czułby się ze swoim teatrem równie nie na miejscu, co aktorka Komedii Francuskiej w fabryce czy średniowieczny klecha przy taśmie produkcyjnej" (Deleuze i Guattari 2017, 133). Oczywiście, tak jak u Marksa materiał, na którym się operuje, nie jest tylko czysto fizyczny, a praca nie jest wyłącznie pracą mięśni, tak samo u D\&G pragnienie nie łączy ze sobą wyłącznie przedmiotów. Możliwe jednak, że w Kapitale dokonana została pewna nazbyt pośpieszna redukcja pracy „niematerialnej” do pracy materialnej. Byłaby to jakaś inna postać naznaczającego to dzieło „problemu redukcji pracy złożonej do pracy prostej” (Harvey 2017, 157). Pojęcie pragnienia, przeciwnie, jest tak skonstruowane, by pokazać, że odpowiada ono również za wytwarzanie idei, afektów, relacji społecznych czy nowych organizmów - obejmuje więc to, co we współczesnym marksizmie nazywa się pracą kognitywną, afektywną i reprodukcyjną. I to właśnie te kwestie, w szczególności wytwarzanie relacji społecznych oraz podmiotów, najbardziej interesuja D\&G. Choć o wiele bliżej im do Marksa niż do Freuda, to ich celem nie jest napisanie nowej wersji Kapitatu. Zajmuja ich nie procesy wytwarzania czy cyrkulacji kapitału, lecz wytwarzania różnych typów społeczeństwa (jak sami mówią: maszyn społecznych) oraz odpowiadających im typów podmiotowości. Za tym zaś idzie odpowiednie przekształcenie pojęcia pragnienia/pracy.

Wydaje się, że najpoważniejszym problemem, na który nie jest w stanie odpowiedzieć, a może nawet w ogóle go zauważyć, teoria Marksa, jest problem pragnienia własnego zniewolenia. W samym sercu projektu D\&G umieszczone zostaje pytanie postawione niegdyś przez Spinozę, a powtórzone przez Reicha: „Dlaczego ludzie walczą za swoje poddaństwo jakby chodziło o ich zbawienie?" (Deleuze i Guattari 2017, 35). Dlaczego ludzie pragna swojej własnej niewoli albo podporządkowania kapitałowi, albo faszystowskiego terroru? I dalej, jak produkowany jest podmiot, który pragnie być proletariuszem bądź prekariuszem? Albo faszystowskim siepaczem? Ponownie, pragnąć nie oznacza tu „zachciewać się czegoš”, ale raczej: „dążyć do...”, „pracować na...”, operować na materii w taki sposób, by generowało to określone efekty. W jaki więc sposób ludzie pracują, działaja w świecie, że sami wytwarzają aparaty własnego ucisku i prześladowania? Pytań tych nie da się postawić, pozostając przy Marksowskiej terminologii3.

Wystarczy jednak do pojęcia pracy wprowadzić pewne modyfikacje - objać nim produkcję afektywną i kognitywną oraz reprodukcję, uzupełnić o kategorie rozkoszy oraz

3 Pewien wyjątek stanowi tu być może tekst Fabryka i społeczeństwo Mario Trontiego (zob. Tronti 2013). 
zapisu/kodowania (o tym dalej) - by osiagnąć niebagatelne efekty4. Przede wszystkim pozbywamy się w ten sposób krępującej niektóre odmiany marksizmu (oraz psychoanalizę) hipotezy represji. Przybiera ona dwie, na pozór odmienne, jednak strukturalnie identyczne, postaci: postępową (celem polityki jest wyzwolenie tłamszonej przez instytucje natury ludzkiej, natury, która sama w sobie jest dobra) oraz konserwatywną (człowiek jest z natury zły, dlatego potrzebuje podporządkować się władzy instytucji, które będą hamowały jego negatywne popędy i pozwolą im się sublimować w społecznie pożyteczne i akceptowalne zachowania). Dla D\&G natura ludzka (tzn. pragnienie) nie jest jednak ani dobra, ani zła zbyt uważnie czytali pisma Marksa, Nietzschego i Spinozy, by bawić się w tego rodzaju moralistykę. Natura, pragnienie to dla nich po prostu proces produkcji, tzn. proces montowania przez pojedynczości (jednostki) pewnych układów maszynowych. To dopiero te układy (np. w postaci instytucji społecznych, dzieł sztuki, rozwiązań technologicznych) mogą być wyzwolicielskie lub represjonujące: zależnie od tego, czy powiększają one zdolność działania poszczególnych pojedynczości, czy też krępuja ją i pozwalają działać tylko w wyznaczonych granicach. D\&G nazywają to różnicą reżimów funkcjonowania pragnienia, uznając jednocześnie tożsamość jego natury (Deleuze i Guattari 2017, 36-38).

Represyjne układy maszynowe nie są więc czymś, co jest narzucane podmiotom z zewnątrz, ale czymś, co drażzy je od wewnątrz, co owe podmioty poniekąd same sobie zgotowały5. Jak zauważaja D\&G przy okazji opisu despotycznej maszyny społecznej: „[z] nowymi grupami perwersów rozpowszechnia się wynalazek despoty (a może to nawet oni sfabrykowali dla niego ten wynalazek), gdy szerza jego chwałę i narzucaja jego władzę w miastach, które zakładają lub podbijają" (Deleuze i Guattari 2017, 227, podkr. CR).

$4 \mathrm{Na}$ marginesie warto zauważyć, że Marksowskie pojęcie pracy wydaje się opierać na wyraźnym rozgraniczeniu sfery wytwarzania materialnego („fizycznego”) oraz szeroko rozumianej sfery reprodukcji (działania libido jako pewnej energii, która napędza pracę produkcji biologicznej i podmiotowej). Jako takie pojęcie to było by dla D\&G samo kategorią myślową przejętą z kapitalizmu - czyli tej maszyny społecznej, której udaje się ostatecznie rozdzielić produkcję społeczną (,pracę”) oraz produkcję pragnąca (,pragnienie”). Marks byłby w tym miejscu jeszcze za mało krytyczny.

5 Kwestia owego narzucania z zewnątrz i drążenia od wewnątrz jest w rzeczywistości o wiele bardziej złożona, jednakże jej omówienie wykracza poza ramy niniejszego artykułu, dotyka bowiem specyfiki Deleuzoguattariańskiej historiozofii. Aby jednak nie pozostawiać Czytelnika i Czytelniczki z niczym, pozwolę sobie na wskazanie pewnego tropu. Otóż sformułowana przez D\&G teoria dziejów opiera się na różnicy pomiędzy wewnętrznymi, ontologicznymi tendencjami maszyn społecznych, a zewnętrznymi ,wyzwalaczami”. Należałoby powiedzieć, że despotyzm (organizacja państwowa) oraz kapitalizm istniały, jako pewne wewnętrzne skłonności, już w społeczeństwach pierwotnych. Te jednakże wynalazły cały szereg mechanizmów odpierających owe tendencje. Dlatego też to dopiero zewnętrzna oraz przypadkowa ingerencja, która zaburzyła owe mechanizmy, pozwoliła na wyłonienie się - kolejno - aparatu państwowego oraz kapitalizmu. Na temat owych wewnętrznych, ontologicznych tendencji każdej maszyny zob. Rudnicki 2015. 
Uprawnione wydaje się skonstatowanie czegoś analogicznego o społeczeństwie kapitalistycznym: w pewnym sensie przedsiębiorcy są tylko wytworem samych proletariuszy, którzy z całą zawziętościa pragną być dyscyplinowani i wyzyskiwani. I nie ustąpią w swym pragnieniu tak łatwo! Albo, jak ujęło to dwóch współczesnych deleuzoguattariaństów: „Ludzie nie są bowiem z natury dobrzy. [...] Co więcej, spontaniczne działania wielości ludzi [...] nie są z konieczności antysystemowe lub zorientowane na wyzwolenie. W rzeczywistości, jak mówi Spinoza, ludzie walczą często o swoją własną niewolę, jak gdyby była ona ich zbawieniem" (Hardt i Negri 2012, 296).

Takie stwierdzenia (pojawiające się zarówno u D\&G, jak i u H\&N) nie są jednak przejawem jakiegoś pesymizmu. Mają one służyć innemu zorientowaniu progresywnej polityki, której nie można już właściwie nazywać polityką emancypacyjną. Nie chodzi bowiem o wyzwolenie (represjonowanej przez instytucje natury ludzkiej czy jednej klasy uciskanej przez druga), lecz o rozmontowywanie, a następnie ponowne - lecz w sposób inny niż dotąd - składanie. Składanie, a nie złożenie raz na zawsze. Schizoanalityk, ten inżynier pragnienia, ma dwa zadania. Po pierwsze, musi nie tylko demontować represyjne układy pragnienia, ale również uczynić $\mathrm{z}$ owego demontażu warunek funkcjonowania samego pragnienia (Deleuze i Guattari 2017, 394). Trzeba tak „ustawić” produkcję pragnąca, by nie zatrzymywała się w momencie wytworzenia produktu - przede wszystkim tego produktu, jakim są formy społeczne: rodzina, paczka przyjaciół, redakcja czasopisma, związek zawodowy, grupa etniczna. Oczywiście rodziny, paczki, redakcje, związki, a nawet grupy etniczne stale się zmieniają: ktoś odchodzi, ktoś przychodzi. Jednak nie tego rodzaju ruch/zatrzymanie mam na myśli. Problemem jest raczej usztywnienie struktury: hierarchia, podział obowiązków, inkluzja wyłącznie pod warunkiem zaakceptowania już istniejących zasad, ważność opinii uzależniona od okresu przynależności itp. Rozmontowywać i montować na nowo trzeba przede wszystkim te "struktury” (układy): gdy nowa pojedynczość dołącza do grupy, musi mieć możliwość nie tylko działania w obrębie zastanych regul, ale przede wszystkim modyfikowania („renegocjowania”) ich samych. Po drugie więc, schizoanalityk musi dbać o to, by do układu były przyłączane coraz to nowe pojedynczości - i to takie, które zapewnią kolejną mutację, które wymuszą renegocjowanie zasad funkcjonowania w kierunku coraz większej otwartości i przyłączalności. Schizo-inżynier musi dbać o to, aby ciało wyposażało się w coraz to nowe organy, rosło, mogło zdziałać więcej, nabierało mocy. Musi to być jednak ciało wielości. 
D\&G pokazuja bowiem - i tu, po tej długiej dygresji, wracam do rozdziału pierwszego - że istnieja dwa różne typy ciał (rozumianych jako pewne „powierzchnie”, do których „przymocowywane” są organy). Jedno z nich nazywają ciałem bez organów6. Jest ono ciałem konkretnej, twórczo i swobodnie pragnącej/pracującej pojedynczości, a może również ciałem wielości (złożonej z) owych pojedynczości. Drugie z nich nazywają socius, czyli ciałem społecznym. Owe ciała produkowane sa przez to samo pragnienie/tę samą pracę, która operuje na materialnych przepływach. Koncepcja takich kolektywnych ciał znowuż - nie jest niczym obcym Marksowi. Swój komentarz o patriarchalnej, wiejskiej produkcji rodziny chłopskiej, w której członkowie dzielą pomiędzy sobą pracę, kończy on słowami: „indywidualne siły robocze z natury rzeczy działaja tu tylko jako organy wspólnej siły roboczej rodziny” (Marks 1950, 83), organy wspólnego ciała. Podobna uwaga pojawia się wówczas, gdy Marks omawia pojęcie kooperacji: współdziałający robotnicy zostaja przez niego nazwani „człon[ami] pewnego organizmu wytwarzającego” (Marks 1950, 359). Wynika z tego, że ciało pragnienia/pracy nie pokrywa się z ciałem biologicznym. Dźwigające barki, produkujące ręce czy kreujące mózgi są zwykle przyłączone do innych ciał, niż sugerowałby to atlas anatomii człowieka. W patriarchalnej, wiejskiej rodzinie będzie to zapewne ciało despotycznego ojca, który zarządza wszystkimi podległymi sobie członkami, który decyduje zarówno o przebiegu pracy, jak i konsumpcji jej wytworów. W społeczeństwie kapitalistycznym, gdzie kooperujący robotnicy, będący „człon[ami] pewnego organizmu wytwarzającego, stanowią tylko szczególny sposób istnienia kapitału” (Marks 1950, 359), to ten ostatni stanowi ciało. W efekcie każda praca (każde pragnienie) działa tak, jak gdyby pochodziła nie od wykonujących ją pojedynczości, ale od socius, którym może być

ciało ziemi, ciało despotyczne bądź kapitał. To o nim Marks powiedział, że nie będąc produktem pracy, wydaje się być jej naturalnym czy boskim założeniem. [...] Nakłada się [ono - przyp. CR] na każdą formę produkcji, ustanawiając powierzchnię, na której dystrybuuje siły i czynniki produkcji, tak że dla siebie przywłaszcza nadwyżkę i sobie przypisuje całość i część procesu, który wydaje się teraz emanować z niego niczym z quasi-przyczyny (Deleuze i Guattari 2017, 13-14, podkr. CR).

6 Bez organów, bo te organy są do niego dopiero „przymocowywane”. 
Sformułowana w Anty-Edypie koncepcja socius byłaby więc swego rodzaju uogólnioną teorią mistyczności kapitału7 lub fetyszyzmu8. Ciało społeczne wytwarza pewną obiektywną iluzję bycia przyczyną wszystkich poszczególnych prac/pragnień i na tej podstawie rości sobie do nich prawo.

Warto przyjrzeć się tej kwestii nieco bliżej. Według D\&G pragnienie/praca z natury, tzn. już w swojej przedkapitalistycznej formie, produkuje nadwyżkę, pewien rodzaj wartości dodatkowej (na temat teorii wartości dodatkowej w Anty-Edypie zob. Swianiewicz 2014, 400_ 452). Jej najbardziej pierwotna postać to wartość dodatkowa kodu. Pragnienie/praca, łącząc ze sobą kolejne organy i przepływy materii, produkuje, jako swoisty efekt uboczny, pewien „schemat działania”, który jest zapisywany - albo kodowany - w nieświadomości. Fragment owego kodu może zostać pobrany i włączony do własnego „schematu działania” przez inną jednostkę bądź grupę. Może to służyć zwiększeniu puli własnych aktywności: D\&G nazywają ten proces stawaniem się. Jednakże zapis może zostać również wykorzystany (na poziomie społecznej nieświadomości) do kodowania długu (braku), którego zwrot następnie się wymusza. Wtłacza się działania jednostek w takie schematy, by wydawało się, że jedne najpierw robią coś dla drugich, i dlatego tamte zobowiązane są do zrekompensowania tego. Nasze codzienne relacje pełne są tego typu kodowania. Za przykład niech posłuży dwójka dorosłych, która pragnie potomstwa i zdaje sobie przy tym sprawę, że posiadanie go będzie od nich wymagało troski o nie, karmienia, codziennej pielęgnacji, wydatków. Wszystkie te działania - podjęte przecież „dla samych siebie” - służą jednak później, gdy dzieci już podrosna, do egzekwowania od nich pewnej wartości w postaci pracy i posłuszeństwa: „to ja, smarkulo, ci dupę podcierałam jak byłaś mała, a ty mi się teraz odmawiasz pójścia po zakupy?!”. Analogicznie działa wiele firm ochroniarskich, które za opłatą strzega przed zagrożeniem (pod postacią wandalizmu, podpalenia), które wpierw same wywołują. Podobny schemat rozumowania obśmiewa też Marks, gdy komentuje klasyczne uzasadnienia przejmowania przez kapitalistę wartości dodatkowej z pracy robotnika: przecież

7 „Wraz z rozwojem wartości dodatkowej bezwzględnej we właściwym, specyficznie kapitalistycznym sposobie produkcji, wskutek czego rozwijają się [także] społeczne siły produkcyjne pracy, wydaje się, że te siły produkcyjne oraz społeczne powiązania pracy [oddzieliły się od procesu produkcyjnego i] przeniosły się z pracy na kapitał. Tym samym kapitał stał się już jakimś bardzo mistycznym zjawiskiem, wydaje się bowiem, że wszystkie społeczne siły produkcyjne pracy są siłami, które należą do niego [...], i że narodziły się z jego własnego łona” (K. Marks, Kapitał. Tom 3, tłum. E. Lipiński, J. Maliniak, Warszawa 1983-1984, s. 571-572, cyt. za: Deleuze i Guattari 2017, 15).

8 Jeśli potraktować fetyszyzm, zgodnie z sugestią Davida Harveya, jako pojęcie kluczowe dla całej konstrukcji Kapitalu (zob. Harvey 2017, 57 oraz 371). 
przedsiębiorca dostarczył pracownikowi środków produkcji oraz środków utrzymania, czyż nie powinien policzyć sobie za tę usługę? (Marks 1950, 204).

Takim postawieniem sprawy D\&G uderzają w klasyczną tezę, jakoby społeczeństwa opierały się na wymianie. Przeciwnie, każdy socius działa w oparciu o wytwarzanie pewnego długu, który należy zwrócić - i to powiększony o pewną wartość dodatkową. Wróćmy do przykładu opieki nad dzieckiem, ale wprowadźmy drobną modyfikację: przywołana wypowiedź podchodzi nie od matki, lecz od babki. Załóżmy, że od czasu do czasu to dziadkowie opiekowali się wnukami, w zamian za to jednak rodzice tychże wyświadczali pewne drobne przysługi - przekopywali ogródek albo podwozili do lekarza. Wymiana, która miała miejsce, była ekwiwalentna. Jeżeli jednak w takich okolicznościach babka odwołuje się do podejmowanego przez siebie wysiłku, by ściagnąć pewna pracę z wnuków, nie ma już mowy o żadnej sprawiedliwej wymianie. Jest to czyste zawłaszczanie wartości dodatkowej. (Dług jest jednak tylko jednym z możliwych typów zapisu. Czy możliwe byłoby zmontowanie socius w inny sposób odnoszącego się do wartości dodatkowej kodu? Czy możliwe jest społeczeństwo stających się?)

Oto dwie najważniejsze składowe pojęcia pragnienia/pracy: produkcja oraz zapis (o konsumpcji wartości dodatkowej - albo jak mówią D\&G: energii resztkowej - nie będę pisał ze względu na skrótowy charakter artykułu). Okazuje się więc, że możliwe jest przedarcie się przez pierwsze paragrafy Anty-Edypa bez odwoływania się do Freuda czy Lacana i pozostanie - mimo odmienności jego języka - bardzo blisko myśli Marksa. Oczywiste jest to również w przypadku rozdziału trzeciego, w którym D\&G próbują skonstruować pewną materialistyczną historiozofię, oraz w odniesieniu do rozdziału czwartego, gdzie ujawniaja się stawki polityczne i dyskutowane są kwestie rewolucji czy interesów klasowych. Na pozór problemem pozostaje rozdział drugi, w którym mowa jedyne o psychoanalizie i gdzie spada nawet liczba odwołań do autora Kapitalu. Czy marksistka znajdzie tu coś dla siebie? By odpowiedzieć na to pytanie, trzeba dobrze zrozumieć, czym jest Edyp. Kilka tropów na zakończenie.

Edyp to nie tytuł perwersyjnej bajki, ale nazwa pewnego kodu społecznego, którego miejscem aplikacji jest instytucja zwana rodziną nuklearną. Edypem nie tyle się jest, co raczej podlega się (niezależnie od płci) edypalizacji, tzn. takiemu zapisowi pragnienia, w efekcie którego zostanie ono naznaczone długiem (brakiem) oraz zorganizowane w indywiduum. Pragnienie/praca nie jest bowiem pragnieniem/pracą osób, ale przedosobowych, 
podindywidualnych obiektów częściowych: jak gdyby odseparowanych organów, narzędzi i materialnych przepływów. Problem ten szczególnie trudny jest do przełknięcia dla marksistów, nawet tych najbardziej heterodoksyjnych (zob. Hardt i Negri 2005, 43). To owe obiekty częściowe są montowane w różnoraki sposób, to je można podłączać do różnych ciał: kapitału czy despoty9 I to również te obiekty częściowe mogłyby swobodnie kooperować, czyli łączyć się w oparciu o pewne horyzontalne i immanentne reguły, gdyby nie... Edyp. Zadaniem Edypa jest wyraźne odseparowanie od siebie poszczególnych układów obiektów częściowych (organów), tak aby powstał indywidualny organizm (już nie ciało) o granicach oddzielających go od innych ${ }^{10}$. Odtąd poszczególne organy będą łączyć się ze sobą tylko za pośrednictwem reguł pochodzących z innego porządku: za przyzwoleniem organizmu. To już nie, jak w pięknym opisie Prousta, pewne usta wyławiają z mgławicy oczu, ust, policzków, nosów, uszu jakiś policzek, który pocałuja (Deleuze i Guattari 2017, 81), ale konkretna Katarzyna, która może pocałować konkretnego Jana jedynie za jego zgodą. Jego lub, w bardziej ogólnym ujęciu, porządku społecznego, do którego należą oboje. Sprywatyzowane ciała moga „kooperować” tylko uzyskawszy pozwolenie z zewnątrz. Marks trafnie rozpoznaje tę sytuację, pisząc o robotnikach najemnych:

[j]ako osoby niezależne, robotnicy są jednostkami, które wstępują w pewien stosunek z tym samym kapitałem, ale nie między soba. Kooperacja ich zaczyna się dopiero w procesie pracy, ale właśnie w procesie pracy przestali oni już należeć do samych siebie. Z chwila wstapienia $\mathrm{w}$ ten proces zostali wcieleni do kapitału (Marks 1950, $359)$.

Robotnicy i robotnice - zindywidualizowane, posiadające określoną tożsamość osobową jednostki - nie są w stanie współdziałać między soba, a jedynie za pośrednictwem kapitału. Albo, odwracając tę formułę: kapitał potrzebuje robotników-jednostek, by móc się jawić (obiektywna iluzja) jako materialny warunek ich współdziałania. Rodzina nuklearna odpowiada za (re)produkcję takich podmiotów, które nie będą w stanie nawiązać współpracy bez pośrednictwa trzeciego elementu. Edyp służy więc kapitalizmowi. Dlatego też każda

9 Jeśli czasem pisałem o pojedynczościach/jednostkach, to tylko celem pewnego uproszczenia.

10 Przypominam: patrzymy tu z perspektywy funkcjonalnej, a nie anatomicznej. Można by jednak powiedzieć, że w wyniku edypalizacji układ funkcjonalny zaczyna pokrywać się - do pewnego stopnia z układem anatomicznym. 
walka z tym ostatnim musi uderzać w rodzinę (a w każdym razie: $\mathrm{w}$ ten określony model rodziny). Gdy D\&G deklaruja, że schizoanaliza ma za zadanie rozbijać „ja” (Deleuze i Guattari 2017, 419), to chodzi im właśnie o pozbycie się owego zorganizowanego (chciałoby się rzec: zorganizmowanego), obdarzonego osobową tożsamością podmiotu. Trzeba go rozbić, tzn. ponownie „sfragmentaryzować, uwolnić przedosobowe, podindywidualne obiekty oraz przepływy, które będa mogły swobodnie kooperować i produkować to, co wspólne. Wydaje się, że Marksowi na chwilę ukazuje się ten wolny i twórczy świat istniejący poza wszelkimi maszynami społecznymi, gdy pisze: „[w] planowanym współdziałaniu z innymi robotnik zaciera granice swej własnej indywidualności i rozwija swą zdolność gatunkową" (Marks 1950, 355). Trzeba by może jedynie słowo „zaciera” zastapić słowem „demontuje”: nie są to bowiem granice naturalne, lecz wyprodukowane. Jednakże demontowanie granic ciał, demontowanie Edypa, demontowanie socius to tylko zadania negatywne, efekty uboczne prawdziwej pracy, która musi wykonać schizo-marksizm, a którą wyraża hasło widniejące na jego sztandarach: Kooperujmy! 


\section{Wykaz literatury}

Deleuze, Gilles, i Félix Guattari. 2017. Anty-Edyp. Kapitalizm i schizofrenia, tom 1. Tłum. T. Kaszubski. Warszawa: Wydawnictwo Krytyki Politycznej.

Harvey, David. 2017. Przewodnik po »Kapitale« Karola Marksa. Cz̨eśc 1. Tłum. Krystian Szadkowski. Poznań: Wydawnictwo Ekonomiczne Heterodox.

Marks, Karol. 1950. Kapitat. Krytyka ekonomii politycznej. Tom 1. Ksiega 1. Tłum. zbiorowe. Warszawa: Książka i Wiedza.

Rudnicki, Cezary. 2015. „Deleuze i Guattari o dwóch zagrożeniach”. Kronos. Metafizyka, kultura, religia 4: 50-66. (https://www.academia.edu/24429858/Deleuze_i_Guattari_o_ dw\%C3\%B3ch_zagro\%C5\%BCeniach, data dostępu: 04.07.2017).

Swianiewicz, Jan. 2014. Możliwość makrohistorii. Braudel, Wallerstein, Deleų̧e. Toruń/Warszawa: Wydawnictwo Naukowe Uniwersytetu Mikołaja Kopernika.

Tronti, Mario. 2013. „Fabryka i społeczeństwo”. Tłum. Sławomir Królak. http://www.praktykateoretyczna.pl/mario-tronti-fabryka-i-spoleczenstwo/ (data dostępu: 04.07.2017). 
Cezary Rudnicki - ur. 1986, nomada i poganin; redaktor i współzałożyciel Machiny Myśli (http://machinamysli.org/) - internetowego portalu popularyzującego filozofię; doktorant w Zakładzie Historii Filozofii Współczesnej UW, gdzie przygotowuje rozprawę poświęconą etyce Siebie; filozoficzny „systemowiec”, który nie cierpi specjalizacji - z tego powodu praktykuje naukowy „chaos”, czyli wielokierunkowe stawanie-się: aktualnie zajmuje się poststrukturalizmem oraz koncepcjami Nietzschego i Abramowskiego, które uzupełnia lektura pism chrześcijańskich świętych i mistyków oraz współczesnych myślicieli włoskich i niemieckich.

\section{DANE ADRESOWE:}

Instytut Filozofii UW

Krakowskie Przedmieście 3

00-927 Warszawa

EMAIL: togashi.furebo@gmail.com

CYTOWANIE: Cezary Rudnicki. 2017. Marks bez organów. Praktyka Teoretyczna 3(25): 384397.

DOI: $10.14746 /$ prt.2017.3.19

AUTHOR: Cezary Rudnicki

TITLE: Marx without organs

ABSTRACT: This text attempts to reveal the relationship between Marx's thought and the ontology of desire presented in Anti-Oedipus. Its key mode of operation, allowing exposure of the relationship between these two philosophical projects, will consist of omitting any references to psychoanalysis. Thus, the basic concepts forming the theoretical grid of AntiOedipus - concepts such as desire, body, unconsciousness, code, lack, and even Oedipus - will be explained without reference to the writings of Freud, Lacan and Melanie Klein. Too much time has been devoted to these last-named, as a result narrowing down the circle of recipients of Deleuze and Guattari's work. It seems that the communication block was created primarily between Anti-Oedipus and the Marxist milieu (not counting a few minor exceptions). This is a channel that should finally be made available.

KEYWORDS: labour, desire, body without organs, fetishism, code, debt, Oedipus. 